\title{
HISTOPATHOLOGY OF ENDOMETRIAL CURETTINGS IN PERIMENOPAUSAL WOMEN WITH ABNORMAL UTERINE BLEEDING
}

\author{
Thukkaram Chitra1, Sekar Manjani², Ramamurthy Madhumittha ${ }^{3}$,Arun B. Harke ${ }^{4}$, Ekambaranathan Saravanan 5 , Sigamani Karthik6, \\ Balakrishnan Shabana ${ }^{7}$
}

1 Professor \& HOD, Department of Pathology, Karpaga Vinayaga Institute of Medical Sciences \& Research Centre, Kanchipuram.

${ }^{2}$ Final Year Post Graduate Student, Department of Pathology, KIMS.

${ }^{3}$ Final Year Post Graduate Student, Department of Pathology, KIMS.

${ }^{4}$ Professor, Department of Pathology, KIMS.

${ }^{5}$ Associate Professor, Department of Pathology, KIMS.

${ }^{6}$ Assistant Professor, Department of Pathology, KIMS.

${ }^{7}$ Assistant Professor, Department of Pathology, KIMS.

\section{ABSTRACT}

\section{BACKGROUND}

Abnormal Uterine Bleeding (AUB) is one of the common complaints in the Gynaecology Outpatient Department. Endometrial sampling by dilatation and curettage is done to find out the aetiology of AUB in perimenopausal women.

\section{OBJECTIVES}

The aim of the study is to find out common histopathological diagnosis of endometrial samples of perimenopausal women with AUB and to categorize the causes in relation to clinical presentation.

\section{RESULTS}

The prospective study was done at the Department of Pathology, Karpaga Vinayaga Institute of Medical Sciences, during the period from June 2013 to August 2015. Perimenopausal women (41-50 yrs.) with AUB were included in the study. The commonest clinical presentation was menorrhagia followed by metrorrhagia. Endometrial samples of all 74 perimenopausal women with AUB were evaluated by histopathological examination. The commonest histopathological finding was proliferative endometrium (23\%) followed by simple hyperplasia (16.2\%), secretory endometrium (14.9\%) and complex hyperplasia (10.8\%). Endometrial carcinoma was diagnosed in 2 patients $(2.7 \%)$.

\section{CONCLUSION}

Endometrial causes of AUB evaluated by histopathological examination of curettings revealed that proliferative and secretory endometrium was the commonest diagnosis followed by simple hyperplasia.

\section{KEYWORDS}

AUB - Abnormal Uterine Bleeding; DUB - Dysfunctional Uterine Bleeding.

HOW TO CITE THIS ARTICLE: Chitra T, Manjani S, Madhumittha R, et al. Histopathology of endometrial curettings in perimenopausal women with abnormal uterine bleeding. J. Evolution Med. Dent. Sci. 2016;5(24):1285-1290,

\section{INTRODUCTION}

Abnormal Uterine Bleeding (AUB) is defined as any uterine bleeding that is more than the normal volume, of longer duration and varying in regularity or frequency. Nearly, $30 \%$ of all gynaecological outpatient attendants are for AUB. (1)

Abnormal Uterine Bleeding (AUB) is a collective terminology that includes both organic and non-organic causes. Dysfunctional Uterine Bleeding (DUB) is a subgroup of AUB that includes abnormal bleeding due to non-organic causes. It is present in $50 \%$ of the women with AUB. An endometrial biopsy is usually done for abnormal uterine bleeding to rule out organic pathology. Age and menstrual history are particularly important, because the aetiologies of abnormal uterine bleeding differ according to the age and menstrual status.(2)

Financial or Other, Competing Interest: None.

Submission 09-02-2016, Peer Review 05-03-2016,

Acceptance 11-03-2016, Published 23-03-2016.

Corresponding Author:

Thukkaram Chitra,

Professor and HOD

Department of Pathology,

Karpaga Vinayaga Institute of Medical Sciences \& Research Centre,

GST Road, Chinna Kolambakkam,

Palayanoor Post, Maduranthagam Tk.,

Kanchipuram-603308.

E-mail: drchitrathukkaram@gmail.com

DOI: $10.14260 /$ jemds $/ 2016 / 301$

\section{AIMS AND OBJECTIVES}

The aim of the study is to determine the histopathological patterns of endometrial curettings in perimenopausal women with abnormal uterine bleeding.

\section{METHODOLOGY}

The prospective study was conducted at the Department of Pathology at Karpaga Vinayaga Institute of Medical Sciences, Chinna Kolambakkam for a period of two years from August 2013 to September 2015. The study was approved by the Institutional Ethics Committee. The study was conducted on 74 consecutive endometrial samples obtained from perimenopausal women by dilatation and curettage.

Patients in the perimenopausal age group presenting to the Gynaecology OPD with symptoms of abnormal uterine bleeding were selected. Complete history including drug history was taken. A complete general examination was done. Routine investigations like complete blood count, bleeding time, clotting time and chest X-ray were done. Ultrasound abdomen and pelvis was performed by an experienced sonologist.

\section{CRITERIA}

Patients with abnormal vaginal bleeding aged 41-50 yrs. (Perimenopausal) years who presented to the Gynaecology Department were included. Patients with systemic diseases, 
IUCD in situ, incomplete history, inadequate samples, bleeding and coagulation defects were excluded.

\section{COLLECTION OF SPECIMEN}

Patients recruited into the study were admitted and endometrial curettage was performed by a gynaecologist. The tissue samples were received in $10 \%$ formalin and sent to the pathology department. After routine processing, tissue sections of 4-6 microns were cut and stained with eosin and haematoxylin. The slides were seen under the light microscope by pathologists and studied for their histomorphological patterns.

\section{RESULTS}

A total of 74 perimenopausal women underwent diagnostic $D$ and $\mathrm{C}$ for AUB during the study period and the curettage was submitted for histopathological examination.

\begin{tabular}{|c|c|c|c|}
\hline Sl. No. & Pattern of Bleeding & Total & $\%$ \\
\hline 1 & Menorrhagia & 43 & 58.1 \\
\hline 2 & Metrorrhagia & 22 & 29.7 \\
\hline 3 & Menometrorrhagia & 7 & 9.5 \\
\hline 4 & Polymenorrhea & 2 & 2.7 \\
\hline & Total & 74 & 100 \\
\hline
\end{tabular}

Analysis of the pattern of bleeding (Table 1) revealed that menorrhagia $(58.1 \%)$ is the most common complaint in the perimenopausal age group followed by metrorrhagia $(22 \%)$.

\begin{tabular}{|c|c|c|}
\hline Cause of AUB & Total & $\%$ \\
\hline Functional causes & 41 & 55 \\
\hline Organic lesions & 33 & 45 \\
\hline Total & 74 & 100 \\
\hline \multicolumn{3}{|c|}{$\begin{array}{c}\text { Table 2: Distribution of Cases of AUB in } \\
\text { Perimenopausal Age Group }\end{array}$} \\
\hline
\end{tabular}

Evaluation of the endometrium revealed various patterns on histopathology (Table 2). Functional causes accounted for slightly more than half of the causes (55\%).

\begin{tabular}{|c|c|c|c|}
\hline Sl. No. & Histopathological Diagnosis & Total & $\%$ \\
\hline 1 & Proliferative pattern & 17 & 23 \\
\hline 2 & Simple hyperplasia & 12 & 16.2 \\
\hline 3 & Secretory pattern & 11 & 14.9 \\
\hline 4 & Complex hyperplasia & 8 & 10.8 \\
\hline 5 & Disordered proliferative endometrium & 5 & 6.8 \\
\hline 6 & Endometrial polyp & 3 & 4.1 \\
\hline 7 & Menstrual phase & 3 & 4.1 \\
\hline 8 & Atrophic endometrium & 2 & 2.7 \\
\hline 9 & Atypical hyperplasia & 2 & 2.7 \\
\hline 10 & Secretory hyperplasia & 2 & 2.7 \\
\hline 11 & Endometrial adenocarcinoma & 2 & 2.7 \\
\hline 12 & Chronic endometritis & 2 & 2.7 \\
\hline 13 & Endometrial metaplasia & 1 & 1.4 \\
\hline 14 & Granulomatous TB & 1 & 1.4 \\
\hline 15 & Hormonal changes & 1 & 1.4 \\
\hline 16 & Irregular shedding & 1 & 1.4 \\
\hline 17 & Mixed pattern & 1 & 1.4 \\
\hline \multicolumn{2}{|c|}{ Total } & $\mathbf{7 4}$ & $\mathbf{1 0 0}$ \\
\hline & Table 3: Histopathological patterns of AUB in \\
& Perimenopausal Women & \\
\hline
\end{tabular}

In the perimenopausal age group (Table 3), the commonest diagnoses were proliferative pattern (23\%) followed by simple hyperplasia $(16.2 \%)$, secretory pattern (14.9\%), complex hyperplasia (10.8\%) and disordered proliferative endometrium $(6.8 \%)$.

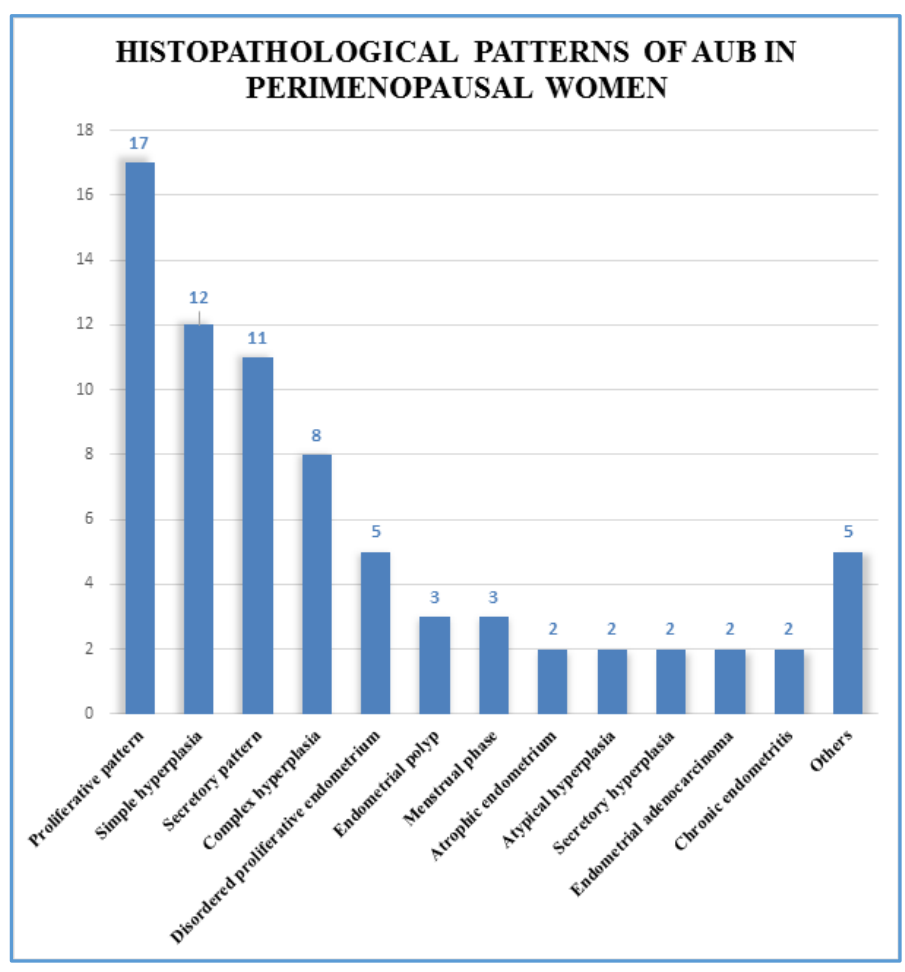

\begin{tabular}{|c|c|c|c|}
\hline $\begin{array}{l}\text { Sl. } \\
\text { No. }\end{array}$ & $\begin{array}{c}\text { Histopathological } \\
\text { Diagnosis }\end{array}$ & Total & $\%$ \\
\hline 1 & Proliferative pattern & 17 & 41.46 \\
\hline 2 & Secretory pattern & 11 & 26.83 \\
\hline 3 & $\begin{array}{l}\text { Disordered proliferative } \\
\text { endometrium }\end{array}$ & 5 & 12.20 \\
\hline 4 & Menstrual phase & 3 & 7.32 \\
\hline 5 & Atrophic endometrium & 2 & 4.88 \\
\hline 6 & Hormonal changes & 1 & 2.44 \\
\hline 7 & Irregular shedding & 1 & 2.44 \\
\hline \multirow[t]{2}{*}{8} & Mixed pattern & 1 & 2.44 \\
\hline & Total & 41 & 100 \\
\hline \multicolumn{4}{|c|}{$\begin{array}{l}\text { Table 4: Nonorganic causes of AUB in } \\
\text { Perimenopausal Women with AUB }\end{array}$} \\
\hline
\end{tabular}

The nonorganic causes (Table 4, Fig. 1-4) of abnormal uterine bleeding in decreasing order of frequency was proliferative pattern $(41.46 \%)$, secretory pattern $(26.83 \%)$, disordered proliferative endometrium (12.22\%), menstrual phase $(7.32 \%)$, atrophic endometrium (4.88\%), hormonal changes $(2.44 \%)$, irregular shedding $(2.44 \%)$ and mixed pattern $(2.44 \%)$. 


\begin{tabular}{|c|c|c|c|}
\hline $\begin{array}{l}\text { Sl. } \\
\text { No. }\end{array}$ & $\begin{array}{l}\text { Histopathological } \\
\text { Diagnosis }\end{array}$ & Total & $\%$ \\
\hline 1 & Simple hyperplasia & 12 & 36.4 \\
\hline 2 & Complex hyperplasia & 8 & 24.2 \\
\hline 3 & Endometrial polyp & 3 & 9.1 \\
\hline 4 & Atypical hyperplasia & 2 & 6.1 \\
\hline 5 & Secretory hyperplasia & 2 & 6.1 \\
\hline 6 & Endometrial adenocarcinoma & 2 & 6.1 \\
\hline 7 & Chronic endometritis & 2 & 6.1 \\
\hline 8 & Endometrial metaplasia & 1 & 3 \\
\hline 9 & Granulomatous TB & 1 & 3 \\
\hline & Total & 33 & 100 \\
\hline \multicolumn{4}{|c|}{$\begin{array}{l}\text { Table 5: Organic causes of AUB in } \\
\text { Perimenopausal Women with AUB }\end{array}$} \\
\hline
\end{tabular}

The organic causes (Fig. 5-8) of abnormal uterine bleeding in this series diagnosed by histopathological examination of $\mathrm{D}$ and $\mathrm{C}$ specimens in decreasing order of frequency are simple hyperplasia (36.4\%), complex hyperplasia $(24.2 \%)$, polyps $(9.1 \%)$, atypical hyperplasia (6.1\%), secretory hyperplasia (6.1\%), endometrial adenocarcinoma (6.1\%), chronic endometritis (6.1\%), endometrial metaplasia (3\%) and granulomatous TB (3\%).

\begin{tabular}{|c|c|c|c|}
\hline Sl. No. & Type & Total & $\mathbf{\%}$ \\
\hline 1 & Simple hyperplasia & 12 & 55 \\
\hline 2 & Complex hyperplasia & 8 & 36 \\
\hline 3 & Atypical hyperplasia & 2 & 9 \\
\hline \multicolumn{2}{|c|}{ Total } & $\mathbf{2 2}$ & $\mathbf{1 0 0}$ \\
\hline \multicolumn{2}{|c|}{ Table 6: Different Types of Endometrial Hyperplasia } \\
\hline
\end{tabular}

\section{DIFFERENT TYPES OF ENDOMETRIAL HYPERPLASIA}

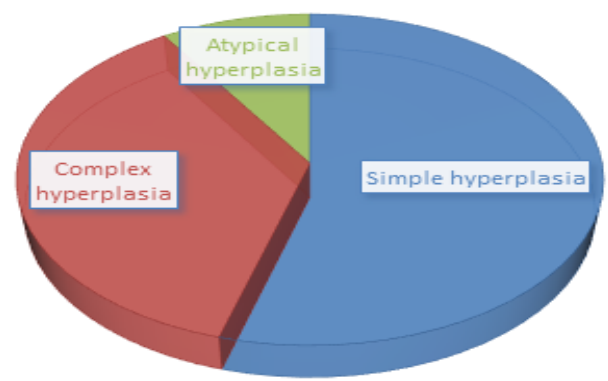

Among the various types of hyperplasias (total=22), simple hyperplasia (55\%) was the commonest type followed by complex hyperplasia (36\%) and atypical hyperplasia (9\%).

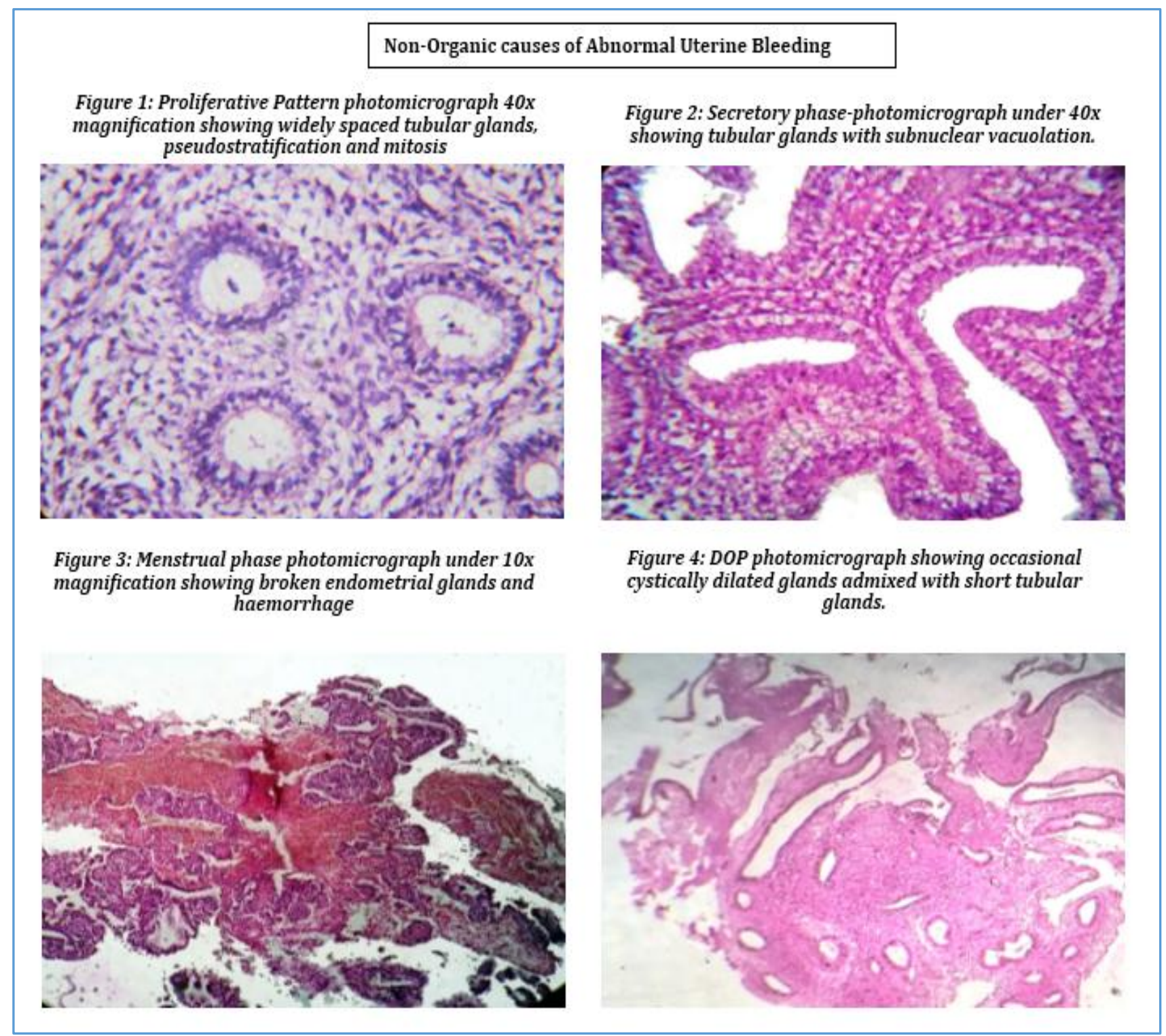




\section{Organic causes of Abnormal Uterine Bleeding}

Figure 5: Simple Hyperplasia under $40 \times$ magnification showing minimally crowded glands with outpouchings.

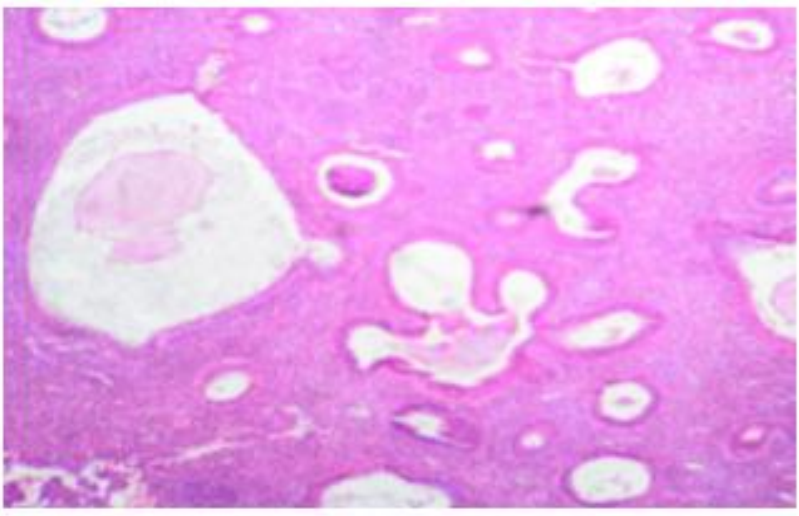

Figure 7: Polyp -under 40x magnification thick walled blood vessels

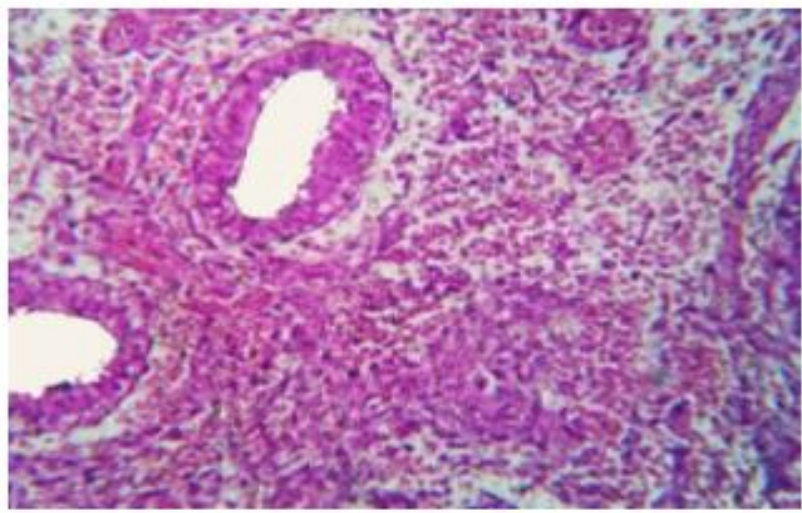

\section{DISCUSSION}

Any vaginal bleeding not satisfying the criteria for normal menstruation is called as abnormal uterine bleeding. It is caused by a wide variety of diseases of the reproductive system as well as non-gynaecologic causes. Organic aetiologies of AUB include diseases of the reproductive tract, iatrogenic and systemic causes. Dysfunctional uterine bleeding can be diagnosed only after all the organic causes of AUB have been excluded.

In this study, only perimenopausal patients were studied as the highest incidence of AUB is in the perimenopausal age group. This is also the commonest age group affected in most of the studies like Soleymani E et al.(3) Shwetha Agrawal et al.(4) Jagadale Kunda et al.(5)
Figure 6: Complex Hyperplasia without atypia-back to back glands with complex branching infoldings and minimal intervening stroma

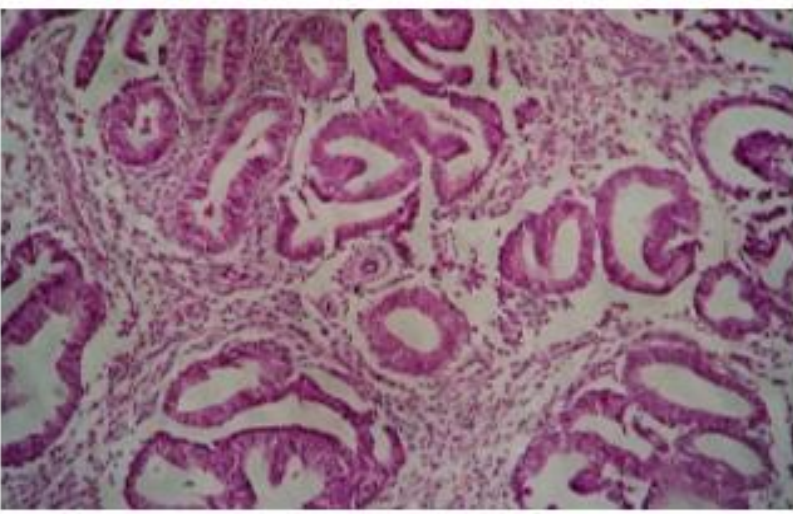

Figure 8: Adenocarcinoma-40x magnification complex branching forming labyrinthine pattern with no intervening stroma

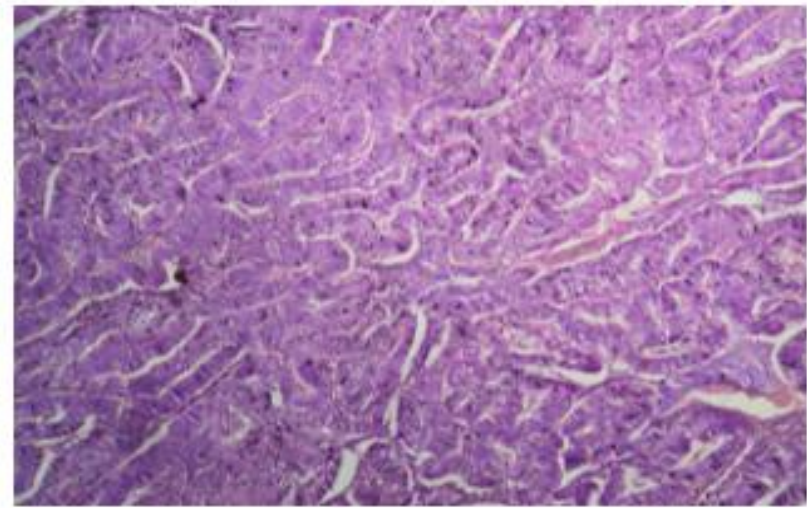

The most common presenting complaint in this study is menorrhagia (58.1\%) followed by metrorrhagia (29.1\%). Menorrhagia is also the commonest complaint in many studies like Sadia Khan et al.(6) Sajitha K et al.(7) Shwetha Agrawal et al.(4) and Jagadale Kunda et al.(5) AUB can be caused by organic or functional (non-organic) causes. In most of the studies, functional causes are common than organic causes. Likewise, functional causes are slightly more common (55\%) than organic causes in this study. This is comparable to findings in studies like Supriya Sandeepa et al.(8) Doraiswami Saraswathi et al.(9) Jagadale Kunda et al.(5) Normal cyclical patterns including proliferative and secretory patterns are the most common histopathological diagnoses seen in most of the studies. This phenomenon is also seen in this study. Both patterns together constitute $37 \%$ of cases in this study. 


\begin{tabular}{|c|c|c|c|c|}
\hline $\begin{array}{l}\text { Sl. } \\
\text { No. }\end{array}$ & Study & \begin{tabular}{|c|} 
Normal Cyclical \\
Pattern \\
(PP+SP) \\
\end{tabular} & DOP & Atrophy \\
\hline 1 & Present study & 37.9 & 6.8 & 2.7 \\
\hline 2 & $\begin{array}{l}\text { Soleymani E et } \\
\text { al.(3) }\end{array}$ & 81.4 & 15.4 & - \\
\hline 3 & $\begin{array}{l}\text { Shwetha Agrawal } \\
\text { et al.(4) }\end{array}$ & 71.75 & - & - \\
\hline 4 & $\begin{array}{l}\text { Zeeba S Jairajpuri } \\
\text { et al.(10) }\end{array}$ & 53.91 & 5.7 & 1.1 \\
\hline 5 & $\begin{array}{l}\text { Supriya Sandeepa } \\
\text { et al.(8) }\end{array}$ & 51.1 & 0.2 & 1.1 \\
\hline 6 & $\begin{array}{l}\text { Layla S Abdullah } \\
\text { et al. }\end{array}$ & 46.6 & 8.7 & 3.1 \\
\hline 7 & $\begin{array}{l}\text { Jagadale Kunda et } \\
\text { al.(5) }\end{array}$ & 44 & - & - \\
\hline 8 & Bhatta S et al.(11) & 42.62 & 6.56 & 7.38 \\
\hline 9 & $\begin{array}{l}\text { Mariam Abid et } \\
\text { al.(12) }\end{array}$ & 34 & - & 6.22 \\
\hline 10 & $\begin{array}{c}\text { Doraiswami } \\
\text { Saraswathi et } \\
\text { al.(9) }\end{array}$ & 28.36 & 20.53 & 2.44 \\
\hline \multicolumn{5}{|c|}{$\begin{array}{c}\text { Table 6: Comparative Study of Incidence of Functional } \\
\text { Causes of AUB (\%) }\end{array}$} \\
\hline
\end{tabular}

PP - Proliferative Pattern; SP - Secretory Pattern.

Hyperplasias constitute $29.7 \%$ of cases of AUB in our study. Simple hyperplasia is present in $16.2 \%$ cases in this study. A similar incidence of hyperplasia is found in studies like Sarwat Ara et al.(13) Nadia Adnan Ghani et al.(14) and Bhoomika Dadhania et al.(15)

The overall risk of progression of hyperplasia to cancer is $5-10 \%$. The risk of progression of simple hyperplasia, complex hyperplasia, simple hyperplasia with atypia and complex hyperplasia with atypia to carcinoma are respectively $1 \%, 3 \%, 8 \%$ and $29 \%$.(16)

The incidence of endometritis in the present study is $2.7 \%$. A high incidence of endometritis is noted in Zeeba S. Jairajpuri et al.(10) Sarwat Ara et al. (13)

\begin{tabular}{|c|c|c|c|c|c|}
\hline $\begin{array}{r}\text { Sl. } \\
\text { No. }\end{array}$ & Study & $\begin{array}{c}\text { Hyper- } \\
\text { plasias }\end{array}$ & Endometritis & Polyp & Malignancy \\
\hline $\mathbf{1}$ & $\begin{array}{c}\text { Present } \\
\text { study }\end{array}$ & & & & \\
\hline $\mathbf{2}$ & $\begin{array}{c}\text { Soleymani } \\
\text { E et al.(3) }\end{array}$ & 2.5 & - & & 0.7 \\
\hline $\mathbf{3}$ & $\begin{array}{c}\text { Layla S } \\
\text { Abdullah } \\
\text { et al. (17) }\end{array}$ & 9.1 & 5.8 & 9.9 & 1.8 \\
\hline $\mathbf{4}$ & $\begin{array}{c}\text { Mariam } \\
\text { Abid et al. } \\
\text { (12) }\end{array}$ & 5 & 12 & 14 & 2 \\
\hline $\mathbf{5}$ & $\begin{array}{c}\text { Supriya } \\
\text { Sandeepa } \\
\text { et al.(8) }\end{array}$ & 17.4 & 0.7 & -1.1 \\
\hline $\mathbf{6}$ & $\begin{array}{c}\text { Shwetha } \\
\text { Agrawal } \\
\text { et al.(4) }\end{array}$ & 16.5 & - & - & 4.5 \\
\hline
\end{tabular}

\begin{tabular}{|c|c|c|c|c|c|}
\hline $\begin{array}{c}\text { Sl. } \\
\text { No. }\end{array}$ & Study & $\begin{array}{c}\text { Hyper- } \\
\text { plasias }\end{array}$ & Endometritis & Polyp & Malignancy \\
\hline $\mathbf{7}$ & $\begin{array}{c}\text { Zeeba S } \\
\text { Jairajpuri } \\
\text { et al.(10) }\end{array}$ & 5.79 & 6.1 & 1.72 & 0.4 \\
\hline $\mathbf{8}$ & $\begin{array}{c}\text { Jagadale } \\
\text { Kunda } \\
\text { et al. (5) }\end{array}$ & 22 & - & 1 & 4 \\
\hline $\mathbf{9}$ & $\begin{array}{c}\text { Bhoomika } \\
\text { Dadhania } \\
\text { et al.(15) }\end{array}$ & 26.66 & 2 & - & 2.66 \\
\hline $\mathbf{1 0}$ & $\begin{array}{c}\text { Doraiswami } \\
\text { Saraswathi } \\
\text { et al.(9) }\end{array}$ & 6.11 & 4.15 & 11.24 & 4.4 \\
\hline $\mathbf{1 1}$ & $\begin{array}{c}\text { Bhatta S } \\
\text { et al.(11) }\end{array}$ & 18.03 & 6.56 & 2.46 & 5.74 \\
\hline \multicolumn{5}{|c|}{ Table 7: Comparative Study of the Incidence of Common } \\
\multicolumn{6}{|c|}{ Organic Causes of AUB (\%) } \\
\hline
\end{tabular}

Polyps are an important organic cause of AUB. The present study reported polyps in $4.1 \%$ of cases. Mariam Abid et al.(12) has the highest incidence of polyps (14\% of cases). In this study, there is an increase in frequency of polyps with increasing age.

Malignancies are less common, but an important cause of abnormal uterine bleeding. In the present study, 2 cases of endometrial carcinoma were seen. Among the malignancies, endometrial carcinoma (Especially endometrioid type) was the commonest reported malignancy in most of the studies. Cases of Malignant Mixed Mullerian Tumour (MMMT), endometrial stromal sarcoma and adenosarcoma were rarely reported in some studies.

\section{CONCLUSION}

AUB is one of the common reasons for visit to the Gynaecology Outpatient Department. The present study showed that the highest incidence of AUB is in the perimenopausal age group (41-50 years). Normal cyclical patterns like proliferative and secretory pattern are the commonest histological diagnosis followed by the simple hyperplasia.

\section{REFERENCES}

1. Dutta D. Textbook of gynecology. 2013; $6^{\text {th }}$ ed.

2. Michael T Mazur, Robert J Kurman. Diagnosis of endometrial biopsies a practical approach. Springer, 2005; $2^{\text {nd }}$ ed.

3. Soleymani E, Ziari K, Rahmani O, et al. Histopathological findings of endometrial specimens in abnormal uterine bleeding. Arch Gynecol Obstet 2014;289(4):845-9.

4. Shweta Agrawal, Asha Mathur, Kusum Vaishnav. Histopathological study of endometrium in abnormal uterine bleeding in women of all age groups in western rajasthan (400 cases). International Journal of Basic and Applied Medical Sciences 2014;4(3):15-18.

5. Jagadale Kunda, Sharma Anupam. Histopathological study of endometrium in abnormal uterine bleeding in reference to different age groups, parity and clinical symptomatology. Int J Clin and Biomed Res 2015;1(2):90-95 
6. Sadia Khan, Sadia Hameed, Aneela Umber. Histopathological pattern of endometrium on diagnosticD \& $\mathrm{C}$ in patients with abnormal uterine bleeding. Annals of KEMU, King Edward Medical University, Lahore, Pakistan 2011;17(2):166-70.

7. Sajitha K, Shetty K Padma, Jayaprakash Shetty K, et al. Study of histopathological patterns of endometrium in abnormal uterine bleeding. Chrismed Journal of Health and Research 2014;1(2):76-81.

8. Supriya Sandeepa, Jayaprakash HT, Ashwini MC. Histopathological study of endometrium in abnormal uterine bleeding in different age groups. International Journal of Scientific Research 2014;3(11).

9. Doraiswami Saraswathi, Johnson Thanka, Rao Shalinee, et al. Study of endometrial pathology in abnormal uterine bleedi. The Journal of Obstetrics and Gynecology of India 2011;61(4):426-430.

10. Zeeba S Jairajpuri, Rana S, Jetley S. Atypical uterine bleeding-histopathological audit of endometrium a study of 638 cases. Al Ameen J Med Sci 2013;6(1):21-28.

11. Bhatta S, Sinha AK. Histopathological study of endometrium in abnormal uterine bleeding. Journal of Pathology of Nepal 2012;2:297-300.
12. Mariam Abid, Atif Ali Hashmi, Babar Malik, et al. Clinical pattern and spectrum of endometrial pathologies in patients with abnormal uterine bleeding in Pakistan: need to adopt a more conservative approach to treatment. BMC Women's Health 2014;14:132.

13. Sarwat Ara, Mahnaz Roohi. Abnormal uterine bleeding; histopathological diagnosis by conventional dilatation and curettage. Professional Med J 2011;18(4):587-591.

14. Nadia Adnan Ghani, Aiad Abdullah Abdulrazak, Ehsan Mahmood Abdullah. Abnormal uterine bleeding: a histopathological study. Diyala Journal of Medicine 2013;4(1).

15. Bhoomika Dadhania, Gauravi Dhruva, Amit Agravat, et al. Histopathological study of endometrium in dysfunctional uterine bleeding. International Journal of Research in Medical Sciences 2013;2(1):20-24.

16. Baak JP, Mutter GL. EIN and WH094. J Clin Pathol 2005;58(1):1-6.

17. Layla S Abdullah, Nabeel S Bondagji. Histopathological pattern of endometrial sampling performed for abnormal uterine bleeding. Bahrain Medical Bulletin 2011;33(4). 